\section{N. Theumann \\ A. Abdelmoumene \\ M. Wintermark \\ P. Schnyder \\ M.-C. Gailloud \\ D. Resnick}

\title{
Posttraumatic pseudolipoma: MRI appearances
}

Received: 10 November 2004

Revised: 11 March 2005

Accepted: 24 March 2005

Published online: 20 April 2005

(C) Springer-Verlag 2005
N. Theumann $(\bowtie) \cdot$

A. Abdelmoumene $\cdot$ M. Wintermark

P. Schnyder · M.-C. Gailloud ·

D. Resnick

Department of Diagnostic and

Interventional Radiology, CHUV,

46 Rue du Bugnon,

1011 Lausanne, Switzerland

e-mail: nicolas.theumann@chuv.hospvd.ch

Tel.: +41-21-3144584

Fax: +41-21-3144554

\begin{abstract}
The goal of this study was to describe the MRI characteristics of posttraumatic pseudolipomas. Ten patients with previous history of blunt trauma or local surgery were investigated with MRI at the level of their deformity. The etiology was blunt trauma in eight patients and postoperative trauma in two. For all patients medical documentation, in the form of clinical history and physical examination, confirmed that a visible hematoma was present acutely at the same location following the injury and that the contour deformity subsequently appeared. All patients underwent liposuction. Preoperative bilateral MRI examinations were performed on all patients. The mean clinical follow-up was 17.8 months. MRI examinations were interpreted in consensus by two experienced musculoskeletal radiologists with attention to fatty extension (subcutaneous fatty thickness and anatomical extension), asymmetry
\end{abstract}

compared with the asymptomatic side, the presence or absence of fibrous septae or nonfatty components, and patterns of contrast enhancement. Ten posttraumatic pseudolipomas were identified. Clinically, they showed as subcutaneous masses with the consistency of normal adipose tissue. Their locations were the abdomen $(n=1)$, hip $(n=1)$, the upper thigh $(n=6)$, the knee $(n=1)$, and the ankle $(n=1)$. On MRI examinations, using the contralateral side as a control, pseudolipomas appeared as focal fatty masses without a capsule or contrast enhancement. Posttraumatic pseudolipomas may develop at a site of blunt trauma or surgical procedures often antedated by a soft tissue hematoma. Characteristic MRI findings are unencapsulated subcutaneous fatty masses without contrast enhancement.

Keywords Magnetic resonance · Lipoma and lipomatosis · Trauma

\section{Introduction}

Lipomas are the most common soft tissue tumors. They are benign mesenchymal neoplasms commonly located in the subcutaneous tissue and occurring in almost all body parts. Most lipomas are solitary lesions; the incidence of multiple lipomas varies from 5 to $15 \%$ [1]. Initially described in 1932 in two patients, Adair et al. [2] defined pseudolipomas as normal adipose tissue that accumulates in abnormal locations [3]. In a recent study, instead of pseudolipomas, Roberts et al. [4] suggested using the terminology of un- encapsulated lipomas for all palpable subcutaneous fatty masses on MRI.

Among pseudolipomas, posttraumatic pseudolipomas remain a poorly recognized and investigated entity. They have been discussed mainly in the dermatology and plastic surgery literature [5-14]. Conversely, there is no report dealing with posttraumatic pseudolipomas in the radiology literature and, more specifically, no reports in which their MRI features have been addressed. The goal of the present study was to describe the MRI characteristics of posttraumatic pseudolipomas. 
Table 1 Clinical presentations

\begin{tabular}{|c|c|c|c|c|c|c|}
\hline & Sex & Age & Mechanisms & $\begin{array}{l}\text { Interval trauma } \\
\text { masses (months) }\end{array}$ & Treatment & Follow-up \\
\hline 1 & Female & 18 & Blunt trauma & 12 & Liposuction & $\begin{array}{l}\text { Clinical ( } 8 \text { months)/ } \\
\text { no recurrence }\end{array}$ \\
\hline 2 & Female & 23 & $\begin{array}{l}\text { Blunt trauma with } \\
\text { evacuated } \\
\text { haematoma }\end{array}$ & 20 & Liposuction & $\begin{array}{l}\text { Clinical (6 months)/ } \\
\text { no recurrence }\end{array}$ \\
\hline 3 & Female & 45 & Blunt trauma & 15 & Liposuction & $\begin{array}{l}\text { Clinical and MRI } \\
\text { ( } 20 \text { months }) / \text { no } \\
\text { recurrence }\end{array}$ \\
\hline 4 & Female & 28 & Blunt trauma & 10 & Liposuction & $\begin{array}{l}\text { Clinical and MRI } \\
\text { (30 months)/no } \\
\text { recurrence }\end{array}$ \\
\hline 5 & Female & 44 & $\begin{array}{l}\text { Blunt trauma with } \\
\text { pelvic fracture }\end{array}$ & 16 & Liposuction & $\begin{array}{l}\text { Clinical and MRI } \\
\text { (10 months)/no } \\
\text { recurrence }\end{array}$ \\
\hline 6 & Female & 47 & Blunt trauma & 15 & Liposuction & $\begin{array}{l}\text { Clinical (36 months)/ } \\
\text { no recurrence }\end{array}$ \\
\hline 7 & Male & 21 & $\begin{array}{l}\text { Torture with } \\
\text { multiple blows }\end{array}$ & 12 & Liposuction & $\begin{array}{l}\text { Clinical and MRI } \\
\text { (18 months)/no } \\
\text { recurrence }\end{array}$ \\
\hline 8 & Male & 20 & $\begin{array}{l}\text { Subcutaneous } \\
\text { injections of growth } \\
\text { hormone }\end{array}$ & 18 & Liposuction & $\begin{array}{l}\text { Clinical and MRI } \\
\text { (11 months)/no } \\
\text { recurrence }\end{array}$ \\
\hline 9 & Female & 45 & $\begin{array}{l}\text { Stripping varicose } \\
\text { veins }\end{array}$ & 14 & $\begin{array}{l}\text { Liposuction with } \\
\text { ultrasound }\end{array}$ & $\begin{array}{l}\text { Clinical and MRI } \\
\text { ( } 21 \text { months)/recurrence } \\
11 \text { month later }\end{array}$ \\
\hline 10 & Female & 62 & Hip surgery & 8 & Liposuction & $\begin{array}{l}\text { Clinical (18 months)/ } \\
\text { no recurrence }\end{array}$ \\
\hline
\end{tabular}

\section{Patients, materials and methods}

\section{Patients}

During the period from 2001 to October 2003, we retrospectively identified ten patients referred to the radiology department by plastic surgeons for evaluation of a contour deformity induced by a palpable fatty mass suggestive of a lipoma. All patients had sustained traumatic injury prior to the appearance of the contour deformity. The mean delay between the injury and the deformity was 14 months (range 8-20 months). No deformation had been present before injury. At that time, for all patients a medical consultation took place. In all cases a medical report confirmed that a visible hematoma was present acutely at the same location following the injury and that the contour deformity subsequently appeared.

All ten patients underwent an MRI examination prior to removal of the mass. Surgery (liposuctions) was performed on all ten patients for aesthetic reasons. All patients had clinical assessments, including one patient who had a follow-up scan (mean 17.8 months, range 6-36 months). Only one patient showed recurrence of the fatty mass, which ap- peared 11 months after surgical treatment. In that case, the mass was not evident clinically after the initial liposuction. This patient underwent a postoperative MRI examination.

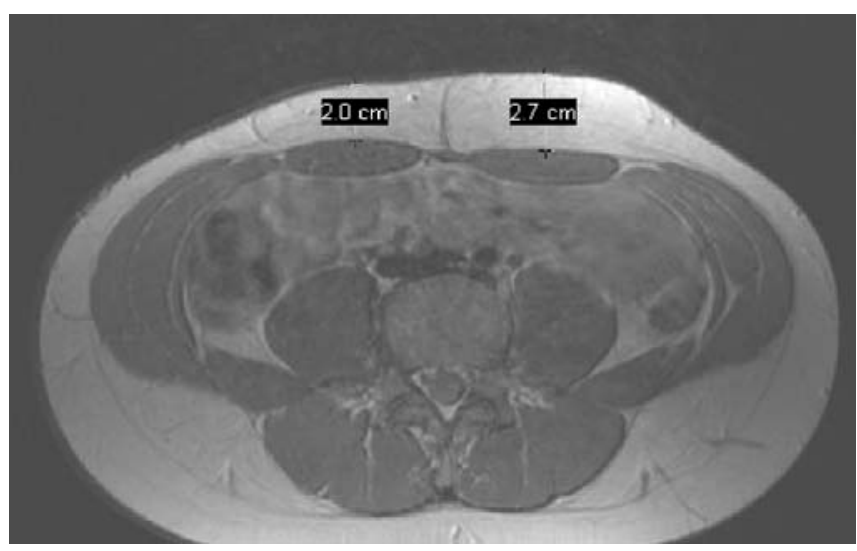

Fig. 1 A 20-year-old man with asymmetrical thickening of the abdominal wall on clinical examination, after subcutaneous injections of growth hormone. Axial T1-weighted spin echo magnetic resonance $(M R)$ image shows asymmetrical thickening of the subcutaneous fat tissue with a posttraumatic pseudolipoma on the left. No septae or contrast enhancement was observed. 
Fig. 2 A 21-year-old man with asymmetrical thickening of the soft tissue of the left ankle following torture with multiple blows in a jailhouse. a Axial T1weighted spin echo and $\mathbf{b}$ axial fat-saturated T1-weighted spin echo post-contrast-injection MR image of the ankle. Asymmetrical thickening of the subcutaneous fat tissue
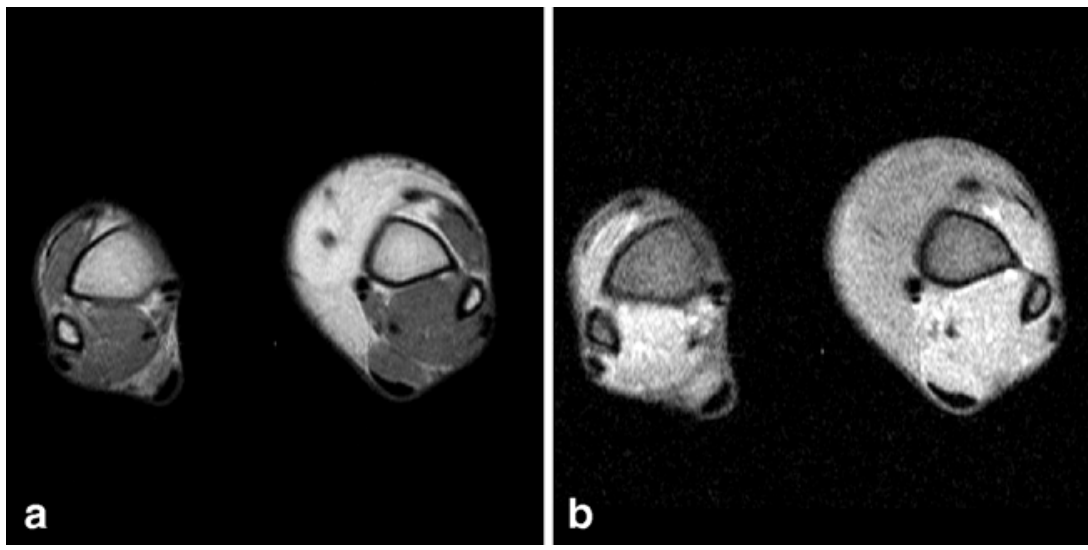

The retrospective study of patient medical charts and magnetic resonance images was approved by our institutional Ethical Committee.

\section{Imaging studies}

All MRI examinations were performed with a 1.5-T magnet (Symphony, Siemens, Erlangen, Germany ) with a body coil or surface-phased array coils. In all cases, both sides of the body were studied. A skin mark was placed on the area of the contour deformity. Six MRI sequences were obtained: axial T1-weighted spin echo images (repetition time, TR, 300-600 ms, echo time, TE, 8-20 ms), axial T2weighted spin echo images with fat saturation (TR 2,500 6,000 ms, TE 60-100 ms), axial T1-weighted spin echo images with fat saturation (TR 300-600 ms, TE 8-20 ms); and axial, sagittal and coronal T1-weighted fat-saturated spin echo images (TR $500 \mathrm{~ms}$, TE $12 \mathrm{~ms}$, slice thickness 5 $\mathrm{mm}$ ) after intravenous injection of gadolinium.

MRI examinations were interpreted in consensus by two experienced musculoskeletal radiologists with attention to fatty extension (subcutaneous fatty thickness and anatomical extension), asymmetry compared with the asymptomatic side, the presence or absence of fibrous septae or nonfatty components, and patterns of contrast enhancement.

\section{Results}

The study population consisted of ten patients (two men and eight women) with a mean age at the time of the first MRI examination of 35.3 years (range 18-62 years). Ten pseudolipomas were identified.

The mechanism of injury (Table 1) included blunt trauma in eight cases and surgery in two cases (varices stripping and orthopaedic hip surgery, respectively). In one case, the fatty mass developed at the site of repetitive subcutaneous injections of growth hormone (Fig. 1).

These masses were located in the abdominal wall $(n=1)$, the hip $(n=1)$, the upper thigh $(n=6)$, the knee $(n=1)$ and the ankle $(n=1)$, respectively.

With MRI , using the contralateral side as a control, all masses presented as homogenous, subcutaneous, unencapsulated fatty tissue (Fig. 2). Contrast enhancement was absent in all cases (Fig. 3). Linear fibrous septae were noted in one case. In the clinical follow-up, no recurrences were noted except in one case. The MRI features of the recur-
Fig. 3 A 45-year-old woman with asymmetrical thickening of the soft tissue of the left thigh and knee following stripping of varicose veins. a Axial T1weighted spin echo and $\mathbf{b}$ axial fat-saturated T1-weighted spin echo post-contrast-injection MR images of the left knee. Medial thickening of the subcutaneous fat tissue. No septae or contrast enhancement was observed.
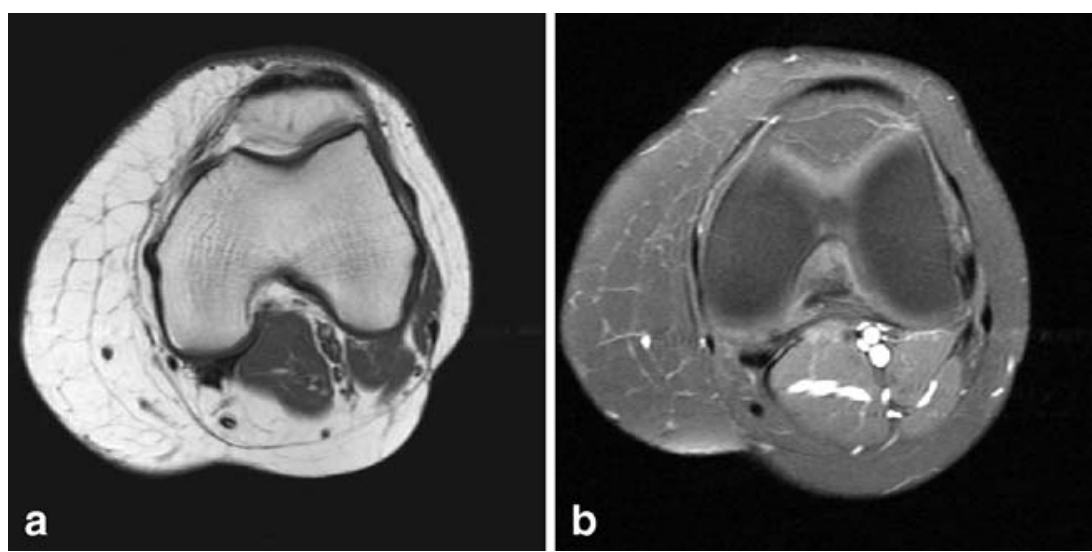
Fig. 4 A 28-year-old woman with asymmetrical thickening of the soft tissue of the left thigh following blunt trauma. a Axial T1-weighted spin echo and $\mathbf{b}$ axial fatsaturated T1-weighted spin echo postcontrast-injection MR image of the thigh. Asymmetrical thickening of the subcutaneous fat tissue facing the hip, with a fibrous septae
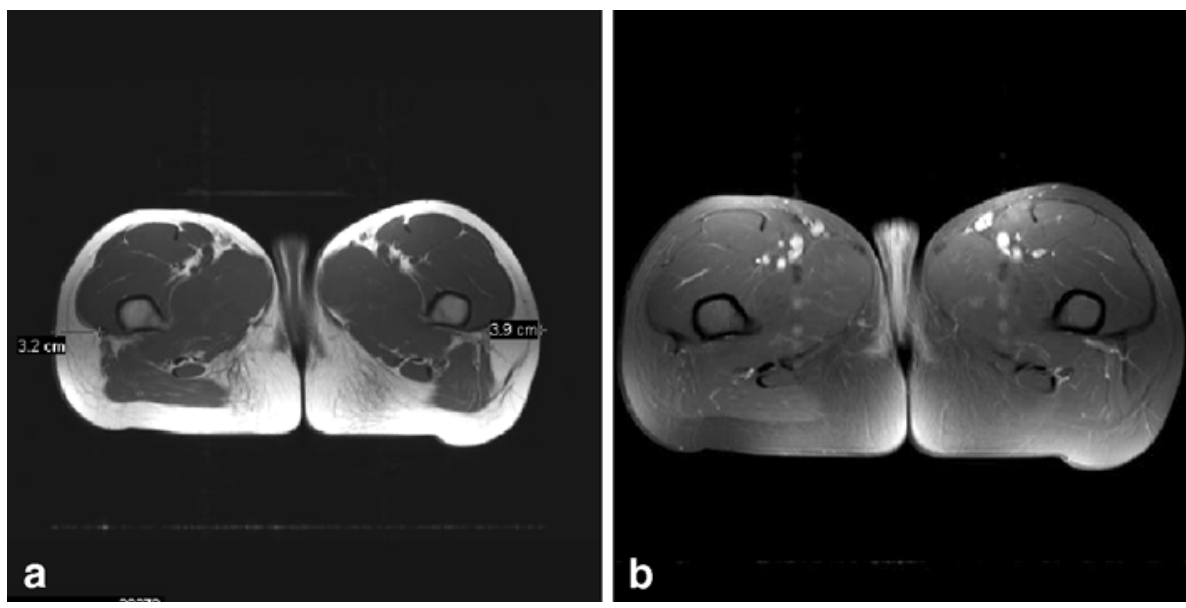

rence were identical to those documented in the preoperative examination (Fig. 4).

\section{Discussion}

A relationship between the occurrence of benign fatty tumors and trauma has long been suggested (Table 2) [3, 7-12,14, 15], since the initial description by Adair et al. [2] in 1932. However the mechanism by which a lipoma or a lipoma-like lesion is induced by injury is still not clearly established.

Originally, a Scarpa's fascia injury resulting from trauma had been hypothesized as being responsible for hip and

Table 2 Literature review of posttraumatic pseudolipomas

\begin{tabular}{|c|c|c|c|c|c|}
\hline Studies & Dates & Authors & $\begin{array}{l}\text { Number } \\
\text { of cases }\end{array}$ & Locations & Etiology \\
\hline 1 & 1969 & $\begin{array}{c}\text { Brooke and } \\
\text { McGregor }\end{array}$ & 5 & $\begin{array}{l}\text { Buccal } \\
\text { mucosa }\end{array}$ & $\begin{array}{l}\text { Nonspecific } \\
\text { trauma }\end{array}$ \\
\hline 2 & 1972 & $\begin{array}{l}\text { Meggit and } \\
\text { Wilson }\end{array}$ & 12 & $\begin{array}{l}\text { Gluteal and } \\
\text { trochanteric }\end{array}$ & $\begin{array}{l}\text { Direct } \\
\text { trauma }\end{array}$ \\
\hline 3 & 1975 & $\begin{array}{l}\text { Herbert and } \\
\text { DeGeus }\end{array}$ & 1 & Abdominal & $\begin{array}{l}\text { Tight } \\
\text { underwear }\end{array}$ \\
\hline 4 & 1977 & $\begin{array}{l}\text { Rozner and } \\
\text { Isaacs }\end{array}$ & 24 & $\begin{array}{l}\text { Thigh and } \\
\text { pelvic }\end{array}$ & $\begin{array}{l}\text { Shearing- } \\
\text { type injury }\end{array}$ \\
\hline 5 & 1988 & Dodenhoff & 1 & Hip & $\begin{array}{l}\text { Direct } \\
\text { trauma }\end{array}$ \\
\hline 6 & 1989 & Elsahy & 5 & Thigh & $\begin{array}{l}\text { Direct } \\
\text { trauma }\end{array}$ \\
\hline 7 & 1992 & $\begin{array}{l}\text { Cormenzano } \\
\text { et al. }\end{array}$ & 3 & Hip & $\begin{array}{l}\text { Nonspecific } \\
\text { trauma }\end{array}$ \\
\hline 8 & 1996 & David et al. & 10 & Hip and thigh & $\begin{array}{l}\text { Nonspecific } \\
\text { trauma }\end{array}$ \\
\hline 9 & 2000 & Simango & 1 & Subpectoral & $\begin{array}{l}\text { Direct } \\
\text { trauma }\end{array}$ \\
\hline
\end{tabular}

thigh pseudolipomas [3]. Herbert and De Geus [8] observed a defect in Scarpa's fascia at the level of a perforating vessel with fat herniation through it. Esahy [11] made a similar observation of herniation of fat normally contained under pressure through disrupted fascial layers. Rozner and Isaacs [9] also suggested that scar retraction after fascial injury led to the development of pseudolipomas. However, in three cases of posttraumatic lipomas of the hip, Penoff [16] could not identify any injury or violation of Scarpa's fascia.

A true adipose neoformation following trauma has been suggested as an alternative pathogenesis for posttraumatic pseudolipomas [13]. The adipose neoformation is induced by local and systemic growth factors and inflammatory mediators, as well as degradation products of the hematoma caused by the trauma. These humoral factors trigger the differentiation of preadipocytes into mature adipocytes [13] Copcu [6] speculated that posttraumatic fat necrosis could also trigger the differentiation of preadipocytes, resulting in the formation of the lipoma.

Pseudolipomas are palpable masses that are often more apparent clinically than radiologically. They may be undetected with MRI if they do not produce a contour abnormality of the overlying skin. The visibility of the contour deformity may be position-dependent; the deformity may disappear when compressed by the table or surface coil at the time of the MR examination. Ultrasound could be efficient in determining the nature of such a lesion, especially when the lesions are position-dependent [17].

On MRI examinations, pseudolipomas appear as superficial homogeneous masses blending with the surrounding subcutaneous fat. They appear as a thickening of the subcutaneous fat in the injured areas rather than as a distinct mass. Unlike lipomas, pseudolipomas do not possess a fibrous capsule of low signal intensity. Rather the entire lesion has signal intensity identical to that of subcutaneous fat for all pulse sequences. There are no specific findings, such as hemosiderin deposits or scar tissue, that confirm a posttraumatic lesion. It should be noted, however, that for one of our patient, MRI demonstrated the presence of fibrous sep- 
tae, appearing as linear areas of decreased signal intensity for all pulse sequences. No discernible enhancement can be noted after the intravenous administration of gadolinium chelates. No diffusion-weighted MRI examinations were performed to characterize such tumors [18-20]

The actual recommended treatment for pseudolipomas is liposuction. The benefits of liposuction are smaller and hardly visible scars and a better clinical outcome. The major drawback of liposuction is the absence of a pathologic specimen that confirms the nature of the deformity. Possible complications could be postoperative seromas, which were not evident in the only postoperative MRI eyxamination performed [21]. In our institution, selective liposuction is classically performed using the blunt dissection technique of Illouz [22]. This method achieved excellent results without complications for all patients in our series.

In cases of pseudolipomas with dense or multiple fibrous septae, or when there exists a clinical or a radiological suspicion of malignancy, a traditional open surgical approach is required, allowing histologic assessment of the resected tissue.

There are several limitations in our study. First, for the ten patients who underwent liposuction, pathologic confir- mation of the MRI diagnosis of posttraumatic pseudolipomas was not possible. However, the clinical follow-up for each patient confirmed the absence of subsequent recurrence, except in one case. Second, no MRI examinations were performed prior to the trauma. However, each patient was clinically examined after the injury, at which time a visible hematoma was reported at the site of injury. The clinical examination further documented that only later did a deformity occur, and it was located in all cases at the precise site of the hematoma.

\section{Conclusion}

Posttraumatic pseudolipomas may develop at a site of blunt trauma or surgical procedures often antedated by a soft tissue haematoma. Characteristic MRI findings are unencapsulated subcutaneous fatty masses without contrast enhancement.

Acknowledgement We acknowledge G. Wintermark for her help in editing this manuscript.

\section{References}

1. Kransdorf MJ, Murphey MD (1997) Lipomatous tumours. In: Kransdorf M, Murphey M (eds) Imaging of soft tissue tumours. Saunders, Philadelphia pp 57-101

2. Adair F, Pack G, Farrior J (1932) Lipomas. Am J Cancer 16:1104

3. Brooke RI, MacGregor AJ (1969) Traumatic pseudolipoma of the buccal mucosa. Oral Surg Oral Med Oral Pathol 28:223-225

4. Roberts CC, Liu PT, Colby TV (2003) Encapsulated versus nonencapsulated superficial fatty masses: a proposed MR imaging classification. Am J Roentgenol 180:1419-1422

5. Abner ML (2001) Lipoma of the abdomen after suction lipectomy. Plast Reconstr Surg 107:293

6. Copcu E (2003) Can intramuscular lipoma have a post-traumatic origin? Br J Dermatol 149:1084-1085

7. Meggitt BF, Wilson JN (1972) The battered buttock syndrome - fat fractures. A report on a group of traumatic lipomata. Br J Surg 59:165-169

8. Herbert DC, DeGeus J (1975) Posttraumatic lipomas of the abdominal wall. Br J Plast Surg 28:303-306
9. Rozner L, Isaacs GW (1977) The traumatic pseudolipoma. Aust N Z J Surg 47:779-782

10. Dodenhoff T (1988) Trauma induced saddle bag: case report. Lipoplasty Newsletter 5:55

11. Elsahy N (1989) Post traumatic fatty deformities. Eur J Plast Surg 12:208

12. David LR, DeFranzo A, Marks M, Argenta LC (1996) Posttraumatic pseudolipoma. J Trauma 40:396-400

13. Signorini M, Campiglio GL (1998) Posttraumatic lipomas: where do they really come from? Plast Reconstr Surg 101:699-705

14. Simango S, Ramdial PK, Madaree A (2000) Subpectoral post-traumatic lipoma. Br J Plast Surg 53:627-629

15. Cormenzana Olaso P, Martinez Florez A, Cecilia Gomez JA (1982) Lipodistrofia post-traumatica. Ibero-Latinoamer 18:47

16. Penoff JH (1982) Traumatic lipomas/ pseudolipomas. J Trauma 22:63-65

17. Inampudi P, Jacobson JA, Fessell DP, Carlos RC, Patel SV, Delaney-Sathy LO, van Holsbeeck MT (2004) Softtissue lipomas: accuracy of sonography in diagnosis with pathologic correlation. Radiology 233:763-767. Epub 2004 Oct 14. PMID: 15486212
18. Dietrich O, Raya JG, Sommer J, Deimling M, Reiser MF, Baur-Melnyk A (2004) A comparative evaluation of a RARE-based single-shot pulse sequence for diffusion-weighted MRI of musculoskeletal soft-tissue tumors. Eur Radiol DOI: 10.1007/s00330-0042619-3

19. Gielen JL, De Schepper AM, Vanhoenacker F, Parizel PM, Wang XL, Sciot R, Weyler J (2004) Accuracy of MRI in characterization of soft tissue tumors and tumor-like lesions. A prospective study in 548 patients. Eur Radiol 14(12):2320-2330

20. Einarsdottir H, Karlsson M, Wejde J, Bauer HC (2004) Diffusion-weighted MRI of soft tissue tumours. Eur Radiol 14(6):959-963

21. Davies AM, Hall AD, Strouhal PD, Evans N, Grimer RJ (2004) The MR imaging appearances and natural history of seromas following excision of soft tissue tumours. Eur Radiol 14(7):11961202

22. Sharma PK, Janniger CK, Schwartz RA, Rauscher GE, Lambert WC (1991) The treatment of atypical lipoma with liposuction. J Dermatol Surg Oncol 17:332324 